\title{
The Role of Transformational Leadership in Promoting Sustainability among Property Development Companies in Malaysia
}

\author{
Norhani Bakri $^{*}$, Salasiah Abbas ${ }^{2}$ \\ ${ }^{1 *}$ School of Human Resource Development and Psychology, Universiti Teknologi Malaysia, Malaysia \\ ${ }^{2}$ Azman Hashim International Business School, Universiti Teknologi Malaysia, Malaysia
}

Keywords:

Transformational Leadership, Sustainability, Property

Development Companies

Received

27 August 2020

Received in revised form

07 September 2020

Accepted

08 September 2020

\begin{abstract}
Sustainability is considered a significant element for property development. However, implementing sustainability effort and achieving sustainability goals are real challenge have debated from three decades ago. According to the United Nations General Assembly Brundtland Report, protecting the environment and the society in the midst of human seeking economic growth is at times taken for granted. The motivation behind this study is to seek deeper understanding of the role of transformational leadership in promoting sustainability among property development companies in Malaysia by determining the relationship between transformational leadership and sustainability in terms of environmental, economy and social. It also analyses whether organisational culture acts as a mediating factor between transformational leadership and sustainability. For this purpose, this study employed a purposive sampling method with data collected from top management from a total population of 100 listed property development companies in Bursa Malaysia. Multivariate data normality tests, descriptive statistics, and structural equation modelling through SmartPLS were used for data analysis. The study revealed a significant positive relationship between transformational leadership and sustainability. It shows that transformational leadership is essential to sustainable achievement where management possess the necessary leadership competencies, skills and knowledge to be able to achieve sustainability in property development. However, the results established insignificant relationship between organisational culture and sustainability. These findings proved that bureaucratic organisational culture mediated the relationship between transformational leadership and sustainability, while innovative culture and supportive culture did not. These results confirmed that bureaucratic culture enhances the role of transformational leadership in promoting sustainability among property development companies in Malaysia. Therefore, this study recommends organisations to invest in transformational leadership trainings to support the leadership behaviours through bureaucratic culture towards achieving sustainability.
\end{abstract}


The challenge of achieving sustainability is faced by all societies and across nations, whether industrialized or developing. Feyerherm and Parker (2015) explained that sustainability is by nature an interdependent and multifaceted phenomenon that integrates the traditional and predominant economic bottom line with social and environmental imperatives. It refers to the ability to ensure the balance of conserving the natural resources, protecting the environment and social fairness while chasing economic growth. In order to achieve sustainability, the three elements of protection of the environment, economic efficiency and social fairness must be combined. Elkington (1999) argued that in order to achieve long-term successful results of sustainable development, all total concept of sustainability considering the perspectives environmental, social as well as economic, needs to be implemented in organisations core business.

In particular, property development poses one of the highest impacts on sustainability. Previous researchers (Bugl, Leimgruber, Huni, \& Scholz, 2009; Kamar, Alshawi, \& Abd Hamid, 2010; Keeping, Dixon, \& Elliso, 2007; Kibert, 2007; Lützkendorf, 2007; Razali \& Adnan, 2015; Sim \& Putuhena, 2015; Thomson \& El-Haram, 2014) have opined that the biggest contributor to the global environmental degradation is the real estate sector. Specifically, in Malaysia, Sim and Putuhena (2015) mentioned that the challenges in adopting green technologies in its construction industry include short of competency and capacity in green technology, overlapping roles of government agencies, slow government programmes, lack of research and innovation and lack of awareness on green implementation cost and benefits. Nevertheless, despite the initiatives taken by the Malaysian government to address sustainability issues in its policies and plans, the country is still behind in terms of implementation and assessment of the implementation (Saadatian et al., 2011). This weakness has been regarded as the absence of comprehensive approaches or frameworks and lack of sufficient sustainable development indicators.

With all the struggles towards sustainability worldwide since 1970s described above, leadership is believed to be one of the key success factors to achieve the targets (Feyerherm \& Parker, 2015). Previous literatures have indicated that one of the attributes of sustainability today is the role of leadership (Chan \& Chan, 2005; Meng, Xue, Liu, \& Fang, 2015; Muralidharan \& Pathak, 2018; Müller \& Jugdev, 2012; Muller \& Turner, 2010; Yang et al., 2011). Researchers believed that while organisations manoeuvre their sustainability strategies, they need to have leadership to guide organisations towards achieving sustainability especially at times of uncertainty and dynamic environment. Dess and Picken (2000) suggest that the demands of the changing environment present a complex set of challenges. It requires a shift in focus where leaders need to meet the challenges by stimulating innovation, creativity, and responsiveness, and learning to manage change without losing strategic focus or spinning out of control.

Muralidharan and Pathak (2018) also highlighted the importance of the role of leadership in developing and implementing agendas for sustainability that in turn maximizes the goals of sustainable development of society. They argued that transformational leaders instill sustainability practices into the fabric of society. Avolio et al (2009) quoted that the transformational leaders "raise followers' aspirations and activate higher order motives (of sustainability), such that followers identify with the leader and his or her mission or vision. Meanwhile, Robertson and Barling (2017a), Graves, Sarkis, and Zhu (2013), and also argued that leaders can encourage their subordinates to engage in workplace pro-environmental behaviors by focusing on the four transformational leadership behaviors. 


\section{Objectives of the Study}

1. To study the relationship between transformational leadership and sustainability at the listed property development companies in Malaysia;

2. To examine the relationship between transformational leadership and organisational culture at the listed property development companies in Malaysia;

3. To understand the relationship between organisational culture and sustainability at the listed property development companies in Malaysia;

4. To analyse if organisational culture mediates the relationship between transformational leadership and sustainability at the listed property development companies in Malaysia.

\section{Research Questions}

1. What is the relationship between transformational leadership and sustainability at the listed property development companies in Malaysia?

2. What is the relationship between transformational leadership and organisational culture at the listed property development companies in Malaysia?

3. What is the relationship between organisational culture and sustainability at the listed property development companies in Malaysia?

4. Does organisational culture mediates the relationship between transformational leadership and sustainability at the listed property development companies in Malaysia?

\section{Research Hypothesis}

$\mathbf{H}_{1}$ : There is a significant relationship between Transformational Leadership and Sustainability in the listed property development companies in Malaysia.

- Hypothesis 1a: There is a significant relationship between idealized influence and sustainability in the listed property development companies in Malaysia.

- Hypothesis $1_{b}$ : There is a significant relationship between inspirational motivation and sustainability in the listed property development companies in Malaysia.

- Hypothesis $1_{c}$ : There is a significant relationship between intellectual stimulation and sustainability in the listed property development companies in Malaysia.

- Hypothesis $1_{\mathrm{d}}$ : There is a significant relationship between individualised consideration and sustainability in the listed property development companies in Malaysia.

H2: There is a significant relationship between Transformational Leadership and Bureaucratic Culture in the listed property development companies in Malaysia.

- Hypothesis 2a: There is a significant relationship between idealized influence and bureaucratic culture in the listed property development companies in Malaysia.

- Hypothesis $2 \mathrm{~b}$ : There is a significant relationship between intellectual stimulation and bureaucratic culture in the listed property development companies in Malaysia. 
- Hypothesis 2 : There is a significant relationship between individualised consideration and bureaucratic culture in the listed property development companies in Malaysia.

- Hypothesis $22_{\mathrm{d}}$ : There is a significant relationship between inspirational motivation and bureaucratic culture in the listed property development companies in Malaysia.

H3: There is a significant relationship between Transformational Leadership and Innovative Culture in the listed property development companies in Malaysia.

- Hypothesis 3a: There is a significant relationship between idealized influence and innovative culture in the listed property development companies in Malaysia.

- Hypothesis 3b: There is a significant relationship between intellectual stimulation and innovative culture in the listed property development companies in Malaysia.

- Hypothesis 3c: There is a significant relationship between individualised consideration and innovative culture in the listed property development companies in Malaysia.

- Hypothesis 3d: There is a significant relationship between inspirational motivation and innovative culture in the listed property development companies in Malaysia.

H4: There is a significant relationship between Transformational Leadership and Supportive Culture in the listed property development companies in Malaysia.

- Hypothesis $4_{\mathrm{a}}$ : There is a significant relationship between idealized influence and supportive culture in the listed property development companies in Malaysia.

- Hypothesis $4_{b}$ : There is a significant relationship between intellectual stimulation and supportive culture in the listed property development companies in Malaysia.

- Hypothesis $4 \mathrm{c}$ : There is a significant relationship between individualised consideration and supportive culture in the listed property development companies in Malaysia.

- Hypothesis $4 \mathrm{~d}$ : There is a significant relationship between inspirational motivation and supportive culture in the listed property development companies in Malaysia.

H5: There is a significant relationship between Bureaucratic Culture and Sustainability in the listed property development companies in Malaysia.

H6: There is a significant relationship between Innovative Culture and Sustainability in the listed property development companies in Malaysia.

H7: There is a significant relationship between Supportive Culture and Sustainability in the listed property development companies in Malaysia.

Hs: Bureaucratic culture has mediating effect on the relationship between transformational leadership and sustainability in the listed property development companies in Malaysia.

H9: Innovative culture has mediating effect on the relationship between transformational leadership and sustainability in the listed property development companies in Malaysia. 
H10: Supportive culture has mediating effect on the relationship between transformational leadership and sustainability in the listed property development companies in Malaysia.

\section{Research Framework}

Figure 1 illustrates the research framework for this study which highlighted the relationships among variables for this study. This model demonstrates an important mechanism through transformational leadership which enhances employee motivation by shaping the appropriate organisational culture and in turn, achieves sustainability. In the same context, this study suggests that organisational culture is an important mediator that could play an effect between transformational leadership and sustainability. Specifically, based on earlier arguments, transformational leadership is expected to have significant impact on organisational culture. As independent variable for this study, the dimensions for transformation leadership consists of individual consideration, inspirational motivation, intellectual stimulation and idealized influence while sustainability as dependent variable were measured based on factors such as environment, economy and society. Meanwhile, the dimensions for organisational culture as mediating variables in this framework include bureaucratic, innovative and supportive factors.

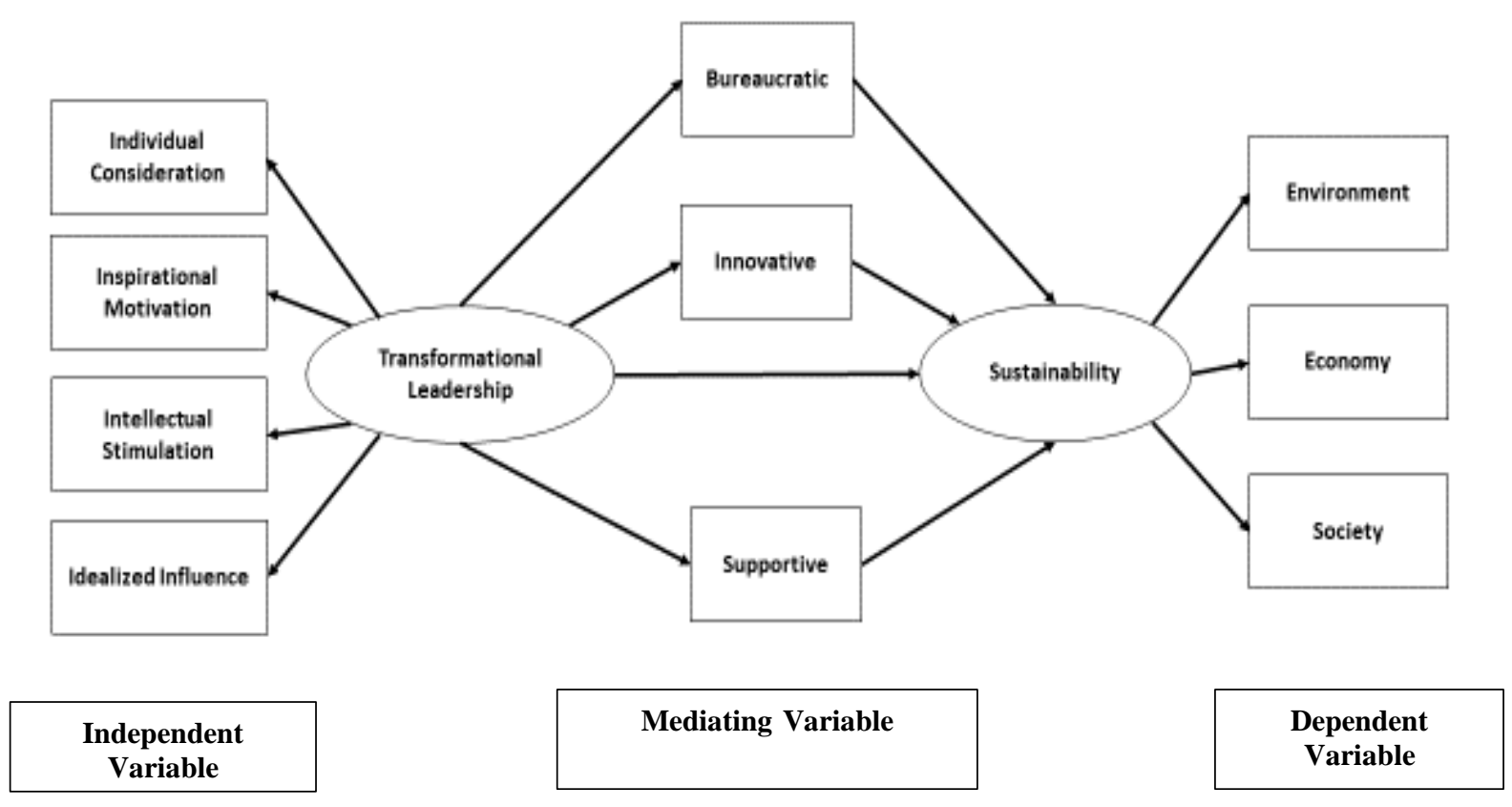

Figure 1. Conceptual model.

The researcher suggests that transformational leadership do have significant impact on sustainability but the mind-set and values of all other individuals and stakeholders of the organisation must also be align with what the leaders and organisation want to achieve. Meanwhile, in the context of built industry in Malaysia, promoting sustainability and facing its challengers, leaders must have adaptability and create organisation systems and initiatives that go beyond their traditional boundaries. Leaders need to go beyond ordinary acts and operate with passion and purpose of all of the individuals involved. Property development companies in Malaysia need 
leadership that provide the vision, strategy and direction towards a sustainable future. This include inspiring, stimulating, motivating and influencing the employees to have common values of sustainability as part of the organisational culture, thus together achieve sustainability goals.

\section{Method}

\section{Respondents' Profile}

The respondents from each company were selected from top management due to their role in decision-making at the management-level of the companies and their responsibilities to nurture their organisation's vision and programs with sustainability elements, and their experiences in dealing with the challenges on embedding organisational culture. Top management refers to seniorlevel leaders including presidents, owners, and other high-ranking executives such as Chief Executive Officer (CEO), Chief Financial Officer (CFO), Chief Operating Officer (COO) and senior-level managers (Al Shobaki, Abu Amuna and Abu Naser, 2016). At the same time, top management plays pivotal role as a leader (Abu Naser et al., 2010, Naser et al., 2016).

A total of 100 respondents participated in this study where majority of them (54\%) aged between 40 to 49 years old. In terms of education qualification level, $74 \%$ of them were Bachelor's degrees' holders, while $13 \%$ of respondents held diploma or postgraduate degrees, respectively. In the meantime, the respondents' years of working experience varies from less than ten years to more than 30 years. The highest percentage of respondents has 21-30 years working experience (45\%), followed by 11-20 years (40\%). Only few of the respondents has more than 30 years working experience $(8 \%)$ and worked less than 10 years $(7$ per cent). This reflect on the top management position that corresponds to their number of years of working experience. The majority of respondents were Senior Managers and General Managers (30\%), followed by Directors (18\%). CEOs also responded as participants (8\%), followed by $\mathrm{COO}$ and Managing Directors (6\% respectively). Lastly, only two CFO participated as respondents (2\%).

\section{Instruments}

Questionnaires were used to obtain information from the management staffs at the property development in Malaysia as respondents. It was developed from the "Transformational Leadership" Short-form Multifactor Leadership Questionnaire (MLQ-5X) by Bass and Avolio (1995), and the "TBL of Sustainability" questionnaire by Elkington (1997). Data was collected through e-mails and phone calls to 100 companies by using the purposive sampling method, to identify the top management staffs to answer the questionnaires. The selection of respondents was based on their position in which reflects on their in providing leadership and decision making. The operational definition of a management staff refers to those who involve in managing subordinates making decisions and also the knowledge and understanding of the respondents on leadership, sustainability and organisational culture of their company. The questionnaire used for this study contained 58 items as follows:

Transformational leadership consists of four dimensions which are Idealized Influence (II) (8 itrms), Inspirational Motivation (IM) (4 items), Intellectual Stimulation (IS) (4 items) and Individualized Consideration (IC) (4 items). The 20 items in the questionnaires are known as the MLQ Form 5X (Avolio \& Bass, 2004).

The second section of this part was designed to measure the three dimensions of organisational culture which are bureaucratic culture ( 8 items), innovative culture ( 8 items) and supportive culture ( 8 items), where the scale questions were adopted from Wallach's (1983) Organisational Culture 
Index (OCI) to determine the culture profile of the organisation.

The third selected survey questionnaire by Høgevold et al. (2015) for this study has items under each dimension of common denominators of Triple-Bottom-Line based on several case studies to be used in this study. The 14 items questionnaire include: a) TBL - General: 5 items, b) TBL Environmental: 3 items, c) TBL - Economic: 3 items, and d) TBL - Society: 3 items.

\section{Reliability and Validity of Instruments Convergent Validity}

In this research, the measurement model's convergent validity was assessed by examining its average variance extracted (AVE) value as the AVE for each individual construct is another important aspect of construct reliability. When its AVE achieves 0.5 or greater the variable should be reliable (Fornell \& Larcker, 1981). In other words, convergent validity is adequate when constructs have an average variance extracted (AVE) value of at least 0.5 or more. For this study, all constructs presented AVE value ranging from 0.518 to 0.631 for first order constructs. Meanwhile, for second order constructs the value of AVE were 0.725 and 0.826 . All of these constructs exceeded the recommended threshold value of 0.5 . These results showed that the research's measurement model has demonstrated an adequate convergent validity and it has been discussed further in the next chapter.

\section{Discriminant Validity}

In this research, the measurement model's discriminant validity was assessed by using two measures: 1) Fornell and Larcker's (1981) criterion, and 2) cross loading. As discussed in earlier chapter, a measurement model has discriminant validity when 1) the square root of the AVE exceeds the correlations between the measure and all other measures, and 2) the indicators' loadings are higher against their respective construct compared to other constructs. Thus, to determine the first assessment of measurement model's discriminant validity, the AVE value of each construct was generated using the SmartPLS algorithm function. Then the square roots of AVE were calculated manually. Based on the results, all square roots of AVE exceeded the off-diagonal elements in their corresponding row and column. Hence, the result confirmed that the Fornell and Larker's criterion was met.

The second assessment of discriminant validity was to examine the indicators' loadings with respect to all construct correlations. The output of the cross loadings was produced by the SmartPLS algorithm function. For this study, results showed the output of cross loading between constructs and indicators. The measurement for all items loaded were higher against their respective intended latent variable compared to other variables. The analysis also demonstrated that the loading of each block was higher than any other blocks in the same rows and columns. The loading clearly separated each latent variable as theorised in the research framework. Thus, the cross-loading output confirmed that the second assessments of the measurement model's discriminant validity were satisfactory. This study therefore concludes that the measurement model has established its discriminant validity and it has been discussed further in the next chapter.

\section{Reliability Test}

In this study, the internal consistency and multi-dimensionality were used. The technique was chosen because it is the most widely-used measure and it is able to provide more accurate reliability estimation. Therefore, the internal consistency assessment using Cronbach's $\alpha$ was carried out for 
all constructs in this study to test the multi-dimensional constructs of transformational leadership, organisational culture and sustainability.

Previous research has also presented the acceptable value for Cronbach's $\alpha$ and most of them point to 0.7 or more (Hair et al., 1998; Hair et al., 2012; Nunnally, 1967; Sekaran, 2003). When the result is 0.7 or more, it implies that all the items forming the constructs are statistically reliable and should not be dropped for further analysis. Hence, based on these views and commonality in quantitative studies, the value of 0.7 was used in this study to test the variables items constructs. Should the value of the Cronbach's $\alpha$ tested is 0.7 or more, it means that the constructs and the items of the study has acceptable reliability values and thus the questionnaire is reliable, usable and suitable for this study.

\section{Data Analysis}

For the purpose of this study, two techniques were utilized to analyse the data from questionnaires collected. These techniques are summarised in Table 1.

Table 1

Data Analysis Techniques

\begin{tabular}{|c|c|c|c|}
\hline No. & Analysis Tool & Purpose & Rationale \\
\hline 1 & $\begin{array}{l}\text { Statistical Package for } \\
\text { Social Science (SPSS) }\end{array}$ & $\begin{array}{l}\text { - To analyse the first part of the questionnaire that represent } \\
\text { the demographic information of respondents } \\
\text { - Management in property development companies } \\
\text { - Includes gender, age, education level, place of work, present } \\
\text { job title, and years of working experience }\end{array}$ & \multirow{2}{*}{$\begin{array}{l}\text { 1. The sample size is } \\
\text { small (200 respondents) } \\
\text { 2. One of the research } \\
\text { objectives is to predict } \\
\text { outcomes using the } \\
\text { model } \\
\text { 3. All constructs in the } \\
\text { proposed model have } \\
\text { minimum of four (4) } \\
\text { items (questions) each }\end{array}$} \\
\hline 2 & $\begin{array}{l}\text { Structural Equation } \\
\text { Modelling (SEM) } \\
\text { approach }\end{array}$ & 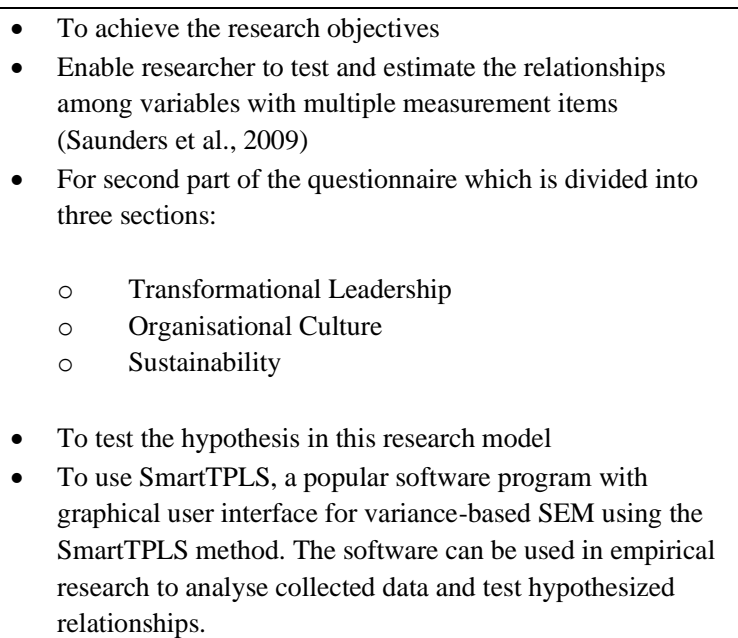 & \\
\hline
\end{tabular}

\section{Results of Structural Model}

Figure 2 shows that sustainability was directly influenced by transformational leadership, $\beta=.27$, $t=2.65, p<.05$. When the 4Is are analysed individually as shown in Figure 3 below, it was directly influenced by idealised influence $(\beta=-.41, t=3.37, p<.05)$ and inspirational motivation $(\beta=.92$, $t=9.31, p<.05)$. However, sustainability was not influenced directly by intellectual stimulation $(\beta$ $=-.09, t=.56, p>.05)$ and individualised consideration $(\beta=-.090, t=.45, p>.05)$. The findings revealed that sustainability was influenced positively by transformational leadership. However, when the 4I's are analysed individually on their relations with sustainability, only individualised consideration and inspirational motivation did not receive statistical support from analysis. 
Based on the analysis, it showed that sustainability was directly influenced by transformational leadership, $\beta=.70, t=2.65, p<.05)$. Similarly, bureaucratic culture, innovative culture and supportive culture were also directly influenced by transformational leadership with the respective value, $\beta=.84, t=29.99, p<.05 ; \beta=.50, t=7.57, p<.05$; and $\beta=.39, t=6.06, p<.05$. As a result, hypothesis $\mathrm{H}_{1}, \mathrm{H}_{2}, \mathrm{H}_{3}$ and $\mathrm{H}_{4}$ were supported. On the other hand, sustainability was influenced directly only by bureaucratic culture $(\beta=.26, t=2.49, p<.05)$ but not by innovative culture $(\beta=$ $.24, t=1.64, p>.05)$ and supportive culture $(\beta=.007, t=.04, p>.05)$. As a result, hypothesis $\mathrm{H}_{5}$ was supported while hypothesis $\mathrm{H}_{6}$ and $\mathrm{H}_{7}$ were not supported.

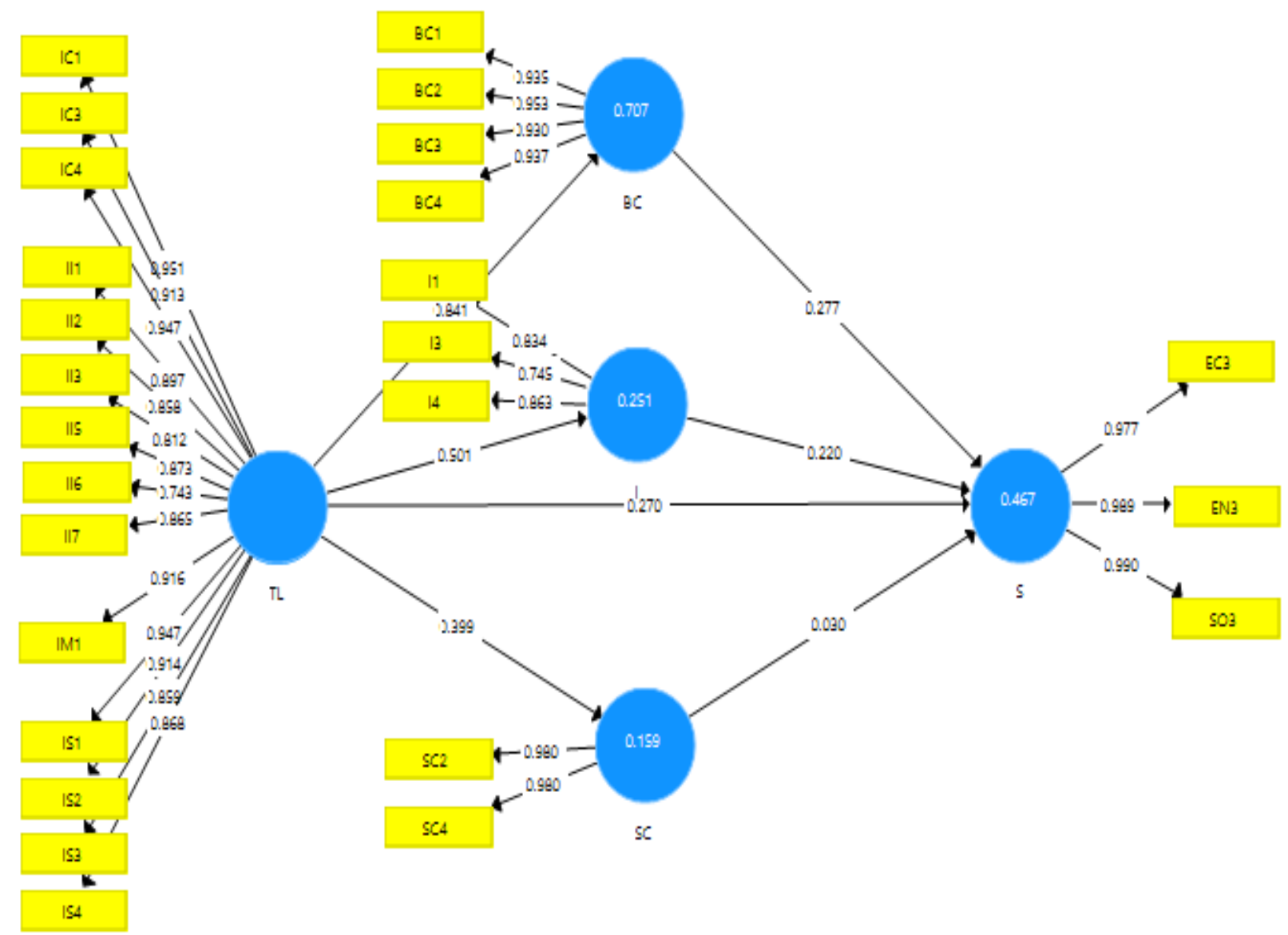

Figure 2. Results of direct relationship where the variables are labelled as TL $=$ Transformational Leadership, II = Idealised Influence, IS = Intellectual Stimulation, IC = Individualised Considerations, IM = Inspirational Motivation, $\mathrm{BC}=$ Bureaucratic Culture, $\mathrm{I}=$ Innovative Culture, $\mathrm{SC}=$ Supportive Culture, $\mathrm{S}=$ Sustainability, EN = Environment and $\mathrm{EC}=$ Economy, $\mathrm{SO}=$ Social 


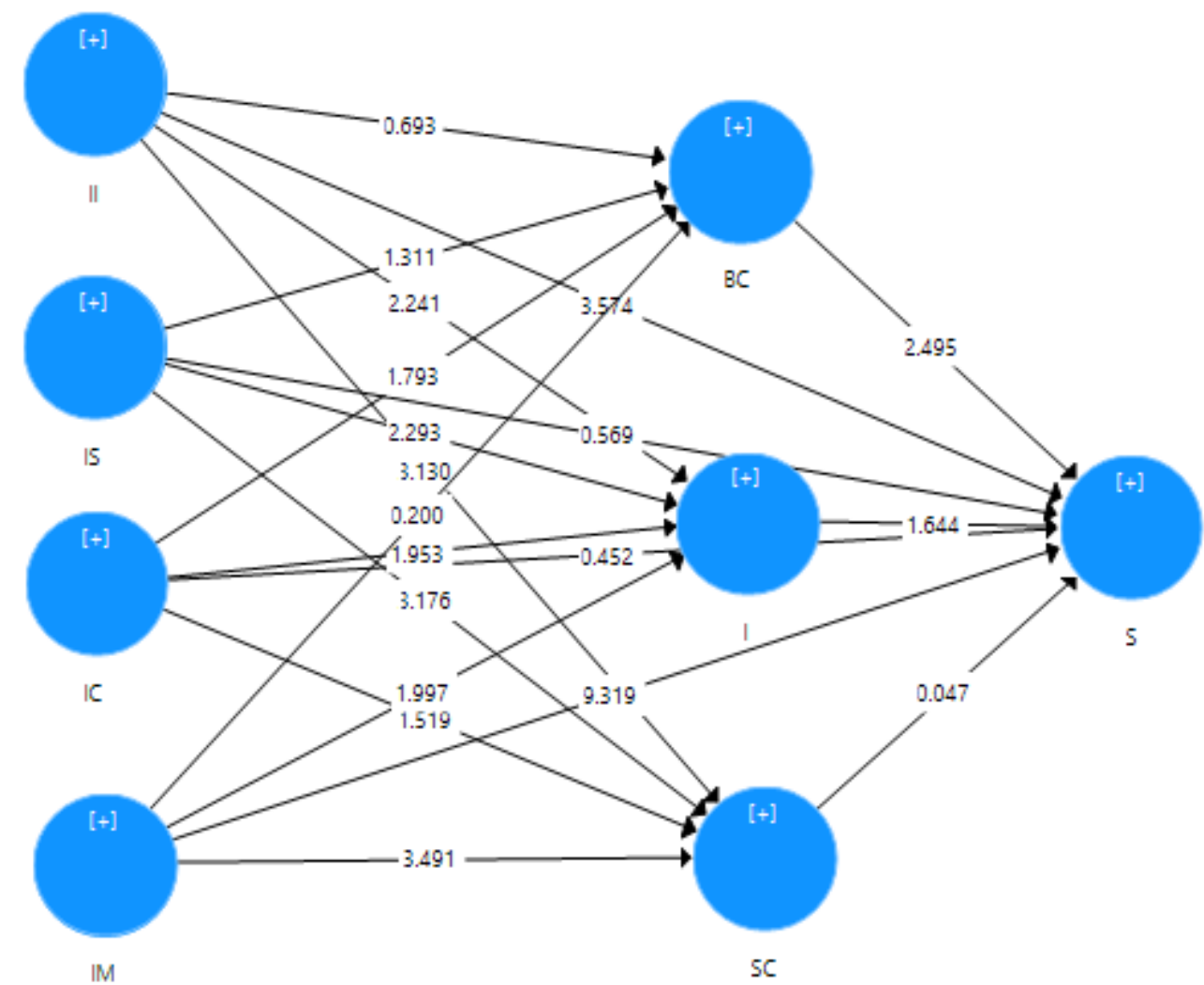

Figure 3. Results of direct relationship where the variables are labelled as II = Idealised Influence, IS = Intellectual Stimulation, IC = Individualised Considerations, IM = Inspirational Motivation, BC = Bureaucratic Culture, $\mathrm{I}=$ Innovative Culture, $\mathrm{SC}=$ Supportive Culture, $\mathrm{S}=$ Sustainability

\section{Results of Hypothesis Testing}

Assessment of the path coefficient of direct relationships shows that all proposed main hypotheses were supported, except for hypotheses $\mathrm{H}_{5}, \mathrm{H}_{6}$ and $\mathrm{H}_{7}$, as presented in Table 2. As for the proposed sub-hypotheses, all of them were not supported, except for sub-hypotheses $\mathrm{H}_{2 \mathrm{a}}, \mathrm{H}_{3 \mathrm{~b}}$ and $\mathrm{H}_{4 b}$. From the analysis, supported hypotheses were significant at least at the level of 0.05 , have both positive and negative directions and consist of a path coefficient value $(\beta)$ ranging from - .54 to .94 .

Based on the research findings, sustainability influenced positively by transformational leadership and organisational culture i.e. bureaucratic culture, innovative culture and supportive culture, were also found to be influenced positively by transformational leadership. However, when the 4I's are analysed individually on their relations with sustainability, only individualised consideration and inspirational motivation that did not receive statistical support from analysis. Similar with organisational culture, when the 4I's are analysed individually, not each of the 4I's are found to be positively influenced by them.

Moreover, the results showed that sustainability was not influenced directly by innovative culture and supportive culture. Sustainability was only influenced directly by bureaucratic culture. As shown in Table 2, a summary of the research hypotheses of the direct relationship were provided under each research question. Overall, from the analysis, five of the seven main hypotheses of the direct relationships $\left(\mathrm{H}_{1}, \mathrm{H}_{2}, \mathrm{H}_{3}, \mathrm{H}_{4}\right.$, and $\left.\mathrm{H}_{5}\right)$ were supported by the empirical findings and two main hypotheses $\left(\mathrm{H}_{6}\right.$ and $\left.\mathrm{H}_{7}\right)$ were not supported. Meanwhile, eight of the sixteen sub-hypotheses of the 
direct relationships $\left(\mathrm{H}_{1 \mathrm{a}}, \mathrm{H}_{1 \mathrm{~d}}, \mathrm{H}_{3 \mathrm{a}}, \mathrm{H}_{3 \mathrm{~b}}, \mathrm{H}_{3 \mathrm{~d}}, \mathrm{H}_{4 \mathrm{a}}, \mathrm{H}_{4 \mathrm{~b}}\right.$, and $\mathrm{H}_{4 \mathrm{~d}}$ ) were supported by the empirical findings while the other eight sub-hypotheses $\left(\mathrm{H}_{1 \mathrm{~b}}, \mathrm{H}_{1 \mathrm{c}}, \mathrm{H}_{2 \mathrm{a}}, \mathrm{H}_{2 \mathrm{~b}}, \mathrm{H}_{2 \mathrm{c}}, \mathrm{H}_{2 \mathrm{~d}}, \mathrm{H}_{3 \mathrm{c}}\right.$, and $\left.\mathrm{H}_{4 \mathrm{c}}\right)$ were not supported.

Table 2

Results of Hypotheses Testing (Direct Relationship)

\begin{tabular}{|c|c|c|c|c|c|c|}
\hline Hypothesis & Sub-Hypothesis & Relationship & $\beta$ & Std Error & $t$ & Decision \\
\hline \multirow[t]{5}{*}{$\mathrm{H}_{1}$} & & TL $\rightarrow S$ & 0.270 & 0.102 & 2.651 & *Supported \\
\hline & $\mathrm{H}_{1 \mathrm{a}}$ & II $>$ S & -0.419 & 0.117 & 3.574 & $* * *$ Supported \\
\hline & $\mathrm{H}_{1 \mathrm{~b}}$ & IS $->S$ & -0.098 & 0.173 & 0.569 & Not supported \\
\hline & $\mathrm{H}_{1 \mathrm{c}}$ & IC $->S$ & -0.090 & 0.199 & 0.452 & Not supported \\
\hline & $\mathrm{H}_{1 \mathrm{~d}}$ & $\mathrm{IM} \rightarrow \mathrm{S}$ & 0.927 & 0.099 & 9.319 & *Supported \\
\hline \multirow[t]{5}{*}{$\mathrm{H}_{2}$} & & $\mathrm{TL} \rightarrow \mathrm{BC}$ & 0.841 & 0.028 & 29.991 & *Supported \\
\hline & $\mathrm{H}_{2 \mathrm{a}}$ & II $->$ BC & 0.116 & 0.168 & 0.693 & Not supported \\
\hline & $\mathrm{H}_{2 \mathrm{~b}}$ & IS -> BC & 0.264 & 0.201 & 1.311 & Not supported \\
\hline & $\mathrm{H}_{2 \mathrm{c}}$ & IC $->B C$ & 0.469 & 0.262 & 1.793 & Not supported \\
\hline & $\mathrm{H}_{2 \mathrm{~d}}$ & $\mathrm{IM}->\mathrm{BC}$ & 0.023 & 0.116 & 0.200 & Not supported \\
\hline \multirow[t]{5}{*}{$\mathrm{H}_{3}$} & & TL -> I & 0.501 & 0.066 & 7.573 & *Supported \\
\hline & $\mathrm{H}_{3 \mathrm{a}}$ & II -> I & -0.333 & 0.149 & 2.241 & $* * *$ Supported \\
\hline & $\mathrm{H}_{3 \mathrm{~b}}$ & IS -> I & 0.719 & 0.313 & 2.293 & *Supported \\
\hline & $\mathrm{H}_{3 \mathrm{c}}$ & IC $\rightarrow>$ I & 0.486 & 0.249 & 1.953 & Not supported \\
\hline & $\mathrm{H}_{3 \mathrm{~d}}$ & IM -> I & -0.382 & 0.192 & 1.997 & $* * *$ Supported \\
\hline \multirow[t]{5}{*}{$\mathrm{H}_{4}$} & & $\mathrm{TL} \rightarrow \mathrm{SC}$ & 0.399 & 0.066 & 6.060 & *Supported \\
\hline & $\mathrm{H}_{4 a}$ & $\mathrm{II}->\mathrm{SC}$ & -0.540 & 0.172 & 3.130 & $* * *$ Supported \\
\hline & $\mathrm{H}_{4 \mathrm{~b}}$ & IS $->$ SC & 0.942 & 0.297 & 3.176 & *Supported \\
\hline & $\mathrm{H}_{4 \mathrm{c}}$ & IC $\rightarrow$ SC & 0.506 & 0.333 & 1.519 & Not supported \\
\hline & $\mathrm{H}_{4 \mathrm{~d}}$ & $\mathrm{IM}->\mathrm{SC}$ & -0.530 & 0.152 & 3.491 & $* * *$ Supported \\
\hline $\mathrm{H}_{5}$ & & $\mathrm{BC} \rightarrow \mathrm{S}$ & 0.265 & 0.106 & 2.495 & *Supported \\
\hline $\mathrm{H}_{6}$ & & $\mathrm{I} \rightarrow \mathrm{S}$ & 0.248 & 0.151 & 1.644 & Not supported \\
\hline $\mathrm{H}_{7}$ & & $\mathrm{SC} \rightarrow \mathrm{S}$ & 0.007 & 0.142 & 0.047 & Not supported \\
\hline
\end{tabular}

Note: ${ }^{*} p<.01, * * p<.05, * * * p<.001$

Based on the mediation analysis, bureaucratic culture mediates the relationship between transformational leadership and sustainability, the indirect effect determined was 0.222 $(0.841 * 0.265)$ and was significant with t-value of $2.18, p<.05$ at $95 \%$ CI [0.023-0.421]; indicating the significance of mediating relationships; thus, $\mathrm{H}_{8}$ was supported. On the other hand, innovative culture did not mediate the relationship between transformational leadership and sustainability, the indirect effect determined was $0.124(0.501 * 0.248)$ and was not significant with t-value of $1.22, p$ $<.05$ at $95 \%$ CI [-0.078-0.277]; indicating the insignificance of mediating relationships; thus, $\mathrm{H}_{9}$ was not supported. Finally, supportive culture also did not mediate the relationship between transformational leadership and sustainability, the indirect effect determined was 0.861 
$(0.399 * 0.113)$ and was not significant with t-value of $.17, p<.05$ at $95 \%$ CI [-0.106-0.169]; indicating the insignificance of mediating relationships thus $\mathrm{H}_{10}$ not supported. Table 3 shows the summary of indirect effect, confidence interval and t-values. Overall, bureaucratic culture was found to have significant mediation effect on the relationship between transformational leadership and sustainability but innovative culture and supportive culture were not.

Table 3

Results of Indirect Effect, Confidence Interval and T-values (Indirect Relationship)

\begin{tabular}{ccccccccc}
\hline & & & \multicolumn{7}{c}{ Bootstrapped Confidence } \\
Interval \\
\hline Hyp & Relationship & Path a & Path b & $\begin{array}{c}\text { Indirect } \\
\text { Effect }\end{array}$ & T-value & $95 \%$ LL & $95 \%$ UL & Result \\
\hline H8 & TL -> BC -> S & .84 & .26 & .22 & 2.18 & 0.023 & .42 & Mediating \\
H9 & TL -> I -> S & .50 & .24 & .12 & 1.22 & -0.078 & .27 & No Mediation \\
H10 & TL > SC -> S & .39 & .11 & .04 & .17 & -0.106 & .16 & No Mediation \\
\hline
\end{tabular}

Note: $\mathrm{TL}=$ Transformational Leadership; $\mathrm{BC}=$ Bureaucratic Culture; I = Innovative Culture; SC = Supportive Culture; $\mathrm{S}=$ Sustainability

\section{Discussion}

In this study, transformational leadership was found to be positively related to sustainability. This result was consistent with previous literature which indicated that one of the attributes of sustainability today is the role of transformational leadership (Baldo \& Baldarelli, 2017; Chan \& Chan, 2005; Feyerherm \& Parker, 2015; Meng et al., 2015; Muralidharan \& Pathak, 2018; Müller \& Judgev, 2012; Muller \& Turner, 2010; Tabassi et al., 2016; Yang et al., 2011). Therefore, transformational leadership is a significant variable for promoting sustainability in property development in Malaysia because it is essential to sustainable achievement where management possess the necessary leadership competencies, skills and knowledge to be able to achieve sustainability in property development.

The role of Transformational leadership is important in ensuring resilient business model through its influence on company performance and organizational outcomes. In terms of social aspect, progress towards the goals of sustainable development is speared by social care that requires active leadership. The importance of leaders' passion has been established and the role of transformational leadership can therefore be inferred to have an important influence on entrepreneurial agency that affects societal change. This showed that most of the respondents indicated that concern for sustainability was an important value within a leader. In other words, the findings have led to the understanding that transformational leadership has positive relationship with sustainability in terms of the three aspects of the TBL which are environment, economy and social.

The results showed that only idealised influence and inspirational motivation were significantly related to sustainability. The other two dimensions namely intellectual stimulation and individualised consideration were found not significantly related to sustainability. This links to the reason that idealised influence and inspirational motivation provide positive influence on creating passion among subordinates. Transformational leaders are more likely to show their passion to subordinates given that transformational leadership relies upon idealised influence and inspirational motivation which have direct impact on individual performance towards achieving sustainability. 
Through these attributes, leaders give vision and mission in order to influence followers to find meanings or purpose in what they do and to achieve. These results can be interpreted that how the listed property development companies in Malaysia use their top management to lead their subordinates towards achieving sustainability goals by inserting influence and giving motivation.

On the other hand, the other two behaviours namely intellectual stimulation and individualised consideration were found not showing positive relations with sustainability. This showed that leaders do not encourage their subordinates' intelligence towards careful problem solving. This is due to the fact that today's leaders deal with the competing demands of simultaneously managing social, environmental as well as financial performance, being held accountable for excellent performance of all of them. This balancing act is not an easy task that transformational leaders are needed to show people the way and stimulate their creativity in solving a global issue. This leads to top management are less engaged in intellectual stimulations. They encourage employees to use non-traditional thinking to deal with problems but not to the extent of challenging their intellect. Moreover, this result can be interpreted how Malaysian property development employees cannot afford dynamic situations of new technologies in built environment. The key is that they prefer not to think outside the box as much as they are influenced by their leader's charismatic leadership. Therefore, these results also confirmed that the attribute intellectual stimulation and individualised consideration should be enhanced to promote sustainability.

Bureaucratic culture mediated the relationship between transformational leadership and sustainability while innovative culture and supportive culture did not. In other words, the relationship between transformational leadership and sustainability was mediated by bureaucratic culture. This finding is in line with previous studies that found the mediating effect of organisational culture (Al-Ali et al., 2017; Cegarra-Leiva et al., 2012; Hussain et al., 2016; Panuwatwanich et al., 2008; Pradhan et al., 2017; Sattayaraksa \& Boon-itt, 2016; Shim, Jo, \& Hoover, 2015; Wipulanusat Panuwatwanich, \& Stewart, 2018;). This finding is rationalised by the influence of transformational leadership itself on sustainability which, as this study revealed, requires mediation of bureaucratic culture in the context of the listed property development companies in Malaysia. This is because charismatic and influential leaders could encourage every participant to achieve organisational vision of sustainability (Meng et al., 2015) and sustainable property development projects through bureaucracy as a significant predictor of employee motivation to achieve and perform. It revealed that top management in the listed property development companies in Malaysia practice clear lines of responsibility and authority. Their leadership is needed to hold the responsibility to ensure sustainability of the organisation and the planet and leaders aspire the sustainability goals.

Therefore, this study has established this mediating link, adopting a sequential approach. First, transformational leadership theory was defined and its effect on sustainability was established. Then, the direct effects of bureaucratic culture on sustainability was found. Finally, bureaucratic culture as a mediating link between transformational leadership and sustainability was established (Hussain, Wan Ismail, Rashid, \& Nisar, 2016). Through the mediating effect, the study recognized the significance of bureaucratic culture in the context of Malaysian setting. In other words, based on this study, it showed that bureaucratic culture reinforced the transformational leadership influences. The success or failure of sustainability depends on many factors, but leadership perhaps the main force that hinders or facilitates it.

This study contributes to the existing knowledge in that leadership is revealed to be a key contributor to sustainability and bureaucratic culture mediated it. Subsequently, it is evident that 
leadership development is a critical area that needs to be addressed in order to achieve sustainability in property development. More leadership training programs need to be developed to shape the present and future projects leaders on how to develop organizational culture that is structured, procedural and stable to ensure sustainability.

\section{Conclusion}

In an industry that plays a vital role in meeting the needs of society and enhancing quality of life in Malaysia, leaders in property development companies give inspirations to their followers to realise sustainability. Without inspirations and motivation, it is challenging to balance profitability with environmental and society elements. In the context of Malaysian property development companies, the study found that the majority of top management engaged in communicating sustainability goals to influence staffs and this finding is significant as it confirms that people need inspiration and motivation to achieve sustainability. Therefore, these companies should focus on hiring managers that have attributes of transformational leadership in order to promote sustainability.

\section{References}

Al-Ali, A. A., Singh, S. K., Al-Nahyan, M., \& Sohal, A. S. (2017). Change management through leadership: The mediating role of organizational culture. International Journal of Organizational Analysis, 25(4), 723-739.

Avolio, B. J., Walumbwa, F. O., \& Weber, T.J. (2009). Leadership: Current theories, research, and future directions. Annual Review Psychology, 60, 421-449.

Avolio, B. J., \& Bass, B. M. (2004). Multifactor leadership questionnaire: The benchmark measure of transformational leadership. Retrieved From Http://Www.Mindgarden.Com/Products/Mlq.Htm

Baldo, M. D., \& Baldarelli, M. G. (2017). Renewing and improving the business model toward sustainability in theory and practice. International Journal of Corporate Social Responsibility, 2(1), 3. https://doi.org/10.1186/s40991-017-0014-Z

Bass, B. M., \& Avolio, B. (1993). Transformational leadership and organizational culture. Public Administration Quarterly, 17(1), $112-121$.

Bass, B. M., \& Avolio, B. J. (1995). Multifactor Leadership Questionnaire (MLQ) [Database record]. APA PsycTests. https://doi.org/10.1037/t03624-000

Bugl, R., Leimgruber, C., Huni, G. R., \& Scholz, R. W. (2009). Sustainable property funds: financial stakeholders views on sustainability criteria and market acceptance, Building Research and Information, 37(3), 246-263.

Cegarra-Leiva, D., Eugenia Sánchez-Vidal, M., \& Gabriel Cegarra-Navarro, J. (2012). Understanding the link between work life balance practices and organisational outcomes in SMEs: The mediating effect of a supportive culture. Personnel Review, 41(3), 359-379. https://doi.org/10.1108/00483481211212986

Chan, A. T. S., \& Chan, E. H. W. (2005). Impact of perceived leadership styles on work outcomes: case of building professionals. Journal of Construction Engineering and Management, 131(4), 413-422.

Dess, G. G., \& Picken, J. C. (2000). Changing roles: leadership in the 21st century. Organisational Dynamics, 28(3), 18-34 https://doi.org/10.1016/S0090-2616(00)88447-8.

Elkington, J. (1997). Cannibals with forks: the triple bottom line for 21 st century business. Capstone, Oxford.

Elkington, J. (1999). Triple bottom-line reporting: looking for balance. Australian CPA, 69, 18-21.

Feyerherm, A. E., \& Parker, S. B. (2015). Chapter 5 emergent collaboration and leadership for sustainable effectiveness: the metropolitan housing authority. In Organizing for Sustainability, 127-153.

Fornell, C., \& Larcker, D. F. (1981). Evaluating structural equation models with unobservable variables and measurement error. Journal of Marketing Research, 18(1), 39-50.

Graves, L. M., Sarkis, J., \& Zhu, Q. (2013). How transformational leadership and employee motivation combine to predict employee proenvironmental behaviors in China. Journal of Environmental Psychology, 35, 81-91.

Hair, J. F., Black, W. C., Babin, B. J., Anderson, R. E., \& Tatham, R. L. (1998). Multivariate Data Analysis with Readings. Englewood Cliffs, NJ: Prentice-Hall.

Hair, J. F., Sarstedt, M., Ringle, C. M., \& Mena, J. A. (2012). An assessment of the use of partial least squares structural equation modeling in marketing research. Journal of the Academy of Marketing Science, 40(3), 414-433. 
Hussain, G., Wan Ismail, W. K., Rashid, M. A., \& Nisar, F. (2016). Substitutes for leadership: Alternative perspectives. Management Research Review, 39(5), 546-568, https://doi.org/10.1108/MRR-03-2015-0044

Kamar, K. A. M., Alshawi, M., \& Abd Hamid, Z. (2010). The critical success factors (CSFS) to industrialised building construction in Malaysia. Paper Presented at CIB World Congress 2010. Retrieved From www.Cream.Com.My/.A.Critical Success-Factors/Download.

Keeping, M., Dixon, T., \& Ellison, L. (2007). The performance of buildings directive and commercial property investment. IPF: London.

Kibert, C. J. (2007). The next generation of sustainable construction. Building and Information. 35(6), 595-601.

Kleindorfer, P. R., Singhal, K., \& Wassenhove, L. N. (2005). Sustainable operations management. Production and Operations Management, 14(4), 482-492.

Lützkendorf, T., \& Lorenz, D. (2007). Integrating sustainability into property risk assessment for market transformation. Building Research and Information, 35(6), 644-661.

Meng, J., Xue, B., Liu, B., \& Fang, N. (2015). Relationships between top managers' leadership and infrastructure sustainability a Chinese urbanization perspective. Engineering, Construction and Architectural Management, 22(6), 692-714.

Muralidharan, E., \& Pathak, S. (2018). Sustainability, transformational leadership and social entrepreneurship. Sustainability, 10(2), 567. doi:10.3390/su10020567

Muller, R., \& Turner, J. R. (2010). Attitudes and leadership competences for project success. Baltic Journal of Management, 5(3), 307-329.

Müller, R., \& Jugdev, K. (2012). Critical success factors in projects: Pinto, Slevin and Prescott - the elucidation of project success. International Journal of Managing Projects in Business, 5(4), 757-775.

Nunnally, J. C. (1967). Psychometric theory. New York: McGraw-Hill.

Panuwatwanich, K., Stewart, R. A., \& Sherif Mohamed (2008). The role of climate for innovation in enhancing business performance: The case of design firms. Engineering, Construction and Architectural Management, 15(5), 407-422, https://doi.org/10.1108/09699980810902712

Pradhan, R. K., Panda, M., \& Jena, L. K. (2017). Transformational leadership and psychological empowerment: The mediating effect of organizational culture in Indian retail industry. Journal of Enterprise Information Management, 30(1), 82-95, https://doi.org/10.1108/JEIM-01-2016-0026

Razali, M. N., \& Adnan, Y. M. (2015). Sustainable property development by Malaysian property companies. Property Management, 33(5), 451-477.

Robertson, J. L., \& Barling, J. (2017a). Contrasting the nature and effects of environmentally-specific and general transformational leadership. Leadership and Organization Development Journal, 38, 22-41.

Robertson, J. L., and Barling, J. (2017b). Toward a new measure of organizational environmental citizenship behavior. Journal of Business Research, 75, 57-66.

Saadatian, O., Lim, C. H., Sohif, M., Sopian, K., and Dalman, M., \& Salleh, E. (2011). Sustainable Development in MalaysiaPlanning and Initiatives, Solar Energy Research Institute. Universiti Kebangsaan Malaysia, Faculty of Design and Architecture, Universiti Putra Malaysia.

Sekaran, U., \& Bougie, R. (2003). Research methods for business: A skill building approach. John Willey \& Sons. Inc: New York.

Shim, S. E, Jo, Y., \& Hoover, L. T. (2015). Police transformational leadership and organizational commitment: Mediating role of organizational culture. Policing: An International Journal of Police Strategies and Management, 38(4), 754-774, https://doi.org/10.1108/PIJPSM-05-2015-0066

Sim, Y. L., \& Putuhena, F. J. (2015). Green building technology initiatives to achieve construction quality and environmental sustainability in the construction industry in Malaysia, Management of Environmental Quality: An International Journal, 26(2), $233-249$.

Tabassi, A. A., Argyropoulou, M., Roufechaei, K. M., \& Argyropoulou, R. (2016). Leadership behavior of project managers in sustainable construction projects. Procedia Computer Science, 100(2016), 724-730.

Thomson, C., \& El-Haram, M. (2014). Potential and implications of sustainability action plans: lessons from the greater Middlehaven regeneration project. Built Environment Project and Asset Management, 4(1), 108-122.

Wallach, E. (1983). Individuals and organisation: the cultural match. Training and Development Journal, 12, 28-36.

Wipulanusat, W., Panuwatwanich, K., \& Stewart, R. A. (2018). Pathways to workplace innovation and career satisfaction in the public service: The role of leadership and culture. International Journal of Organizational Analysis, 26(5), 890-914. https://doi.org/10.1108/IJOA-03-2018-1376

Yang, L. R., Huang, C. F., \& Wua, K. S. (2011). The association among project managers leadership style, teamwork and project success. International Journal of Project Management, 29, 258-267. 